\title{
The PrairieDog: a double-barrel coring drill for 'hand' augering
}

\author{
Jay KYNE, ${ }^{1}$ Joe McCONNELL ${ }^{2}$ \\ ${ }^{1}$ Ice Coring and Drilling Services, Space Science and Engineering Center, University of Wisconsin-Madison, \\ 1225 West Dayton Street, Madison, WI 53706-1612, USA \\ E-mail: jayk@ssec.wisc.edu \\ ${ }^{2}$ Desert Research Institute, 2215 Raggio Parkway, Reno, NV 89512-1095, USA
}

\begin{abstract}
The PrairieDog is a double-barreled ice corer designed to enable more efficient drilling better core quality, fewer trips in and out of the borehole, easier breaks from the hole bottom, better chip collection and less energy to turn - than a simple single core barrel that accompanies most 'hand' ice-coring drill systems. Over several seasons, the PrairieDog has been used to drill about 50 holes to an average depth of about $20 \mathrm{~m}$. It is safe to use in warm ice where a simple core-auguring barrel could easily become stuck. For a $20 \mathrm{~m}$ hole, about five trips in and out of the borehole are saved using the PrairieDog compared with a simple auger barrel of the same core length. With fiberglass inner and outer barrels and an anti-torque section composed primarily of aluminum, the PrairieDog weighs only about $25 \mathrm{lb}(11.3 \mathrm{~kg})$.
\end{abstract}

\section{INTRODUCTION}

The inefficiency of single-barrel hand coring in ice is demonstrated each time the barrel reaches the bottom of the borehole and encounters about $30 \mathrm{~cm}$ of chips from the previous drill run. All the chips on the augering flight - and often some from inside the barrel - fall back into the hole when the single barrel is lifted out of the borehole. This limits the length of recovered core per trip, thus requiring more trips into the hole in order to reach the desired depth. By contrast, a double-barreled corer collects the chips much more efficiently. In the course of normal drilling, the chips are forced into the coring barrel and do not fall back into the borehole from either the barrel or the flights between the inner and outer barrels. In addition, the added stiffness of

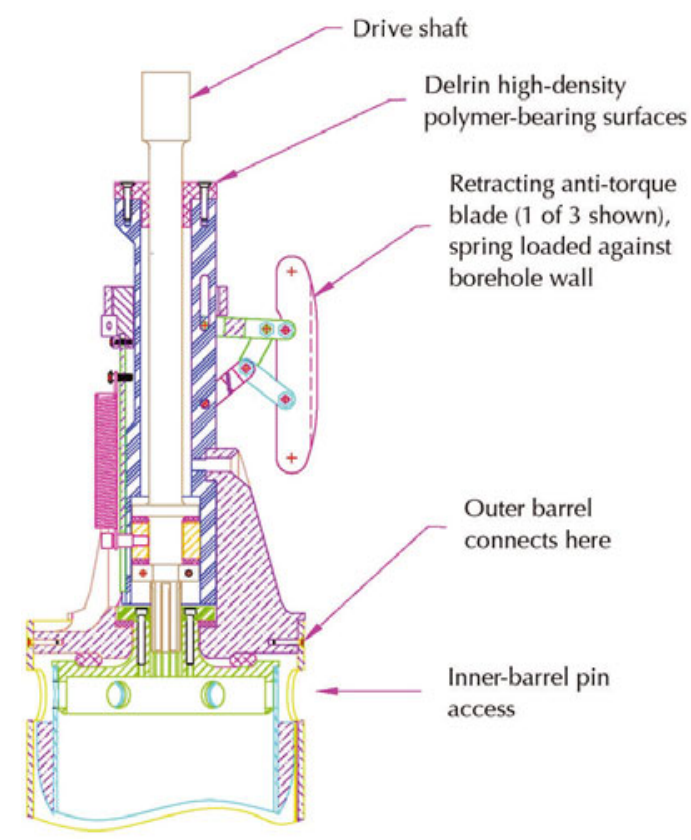

Fig. 1. A sectional view of the PrairieDog anti-torque section as it attaches to the barrels. the double-barrel corer results in fewer breaks in the cores and straighter boreholes, even with the additional weight of a long drill stem.

\section{DESCRIPTION OF THE PRAIRIEDOG}

The PrairieDog consists of an anti-torque section and a barrel section. The anti-torque section (Fig. 1) is about $30 \mathrm{~cm}$ in length and is constructed primarily of aluminum. It is comprised of non-rotating anti-torque blades, a rotating power shaft and the connecting adaptor for the inner barrel. The outer barrel bolts to it as well. A two-position power shaft disengages and engages the anti-torque blades with an upand-down motion. This motion provides a slide-hammer effect when breaking free from the bottom by allowing the drill string above the PrairieDog to gain upward momentum. This reduces the amount of breaking force required from the surface. The anti-torque blades are pressed against the borehole wall by adjustable springs. All bearing surfaces within the anti-torque section are composed of Delrin ${ }^{\circledR}$ (DuPont). While a less expensive leaf-spring style anti-torque would be sufficient, the adjustable spring design used in the PrairieDog ensures that the blades do not slip in the hole. This provides better compaction of the chips and therefore more room for core in the barrel.

The outer barrel (Fig. 2) is constructed from a $1 / 8$ in $(3.2 \mathrm{~mm})$ thick fiberglass/epoxy composite tube which is

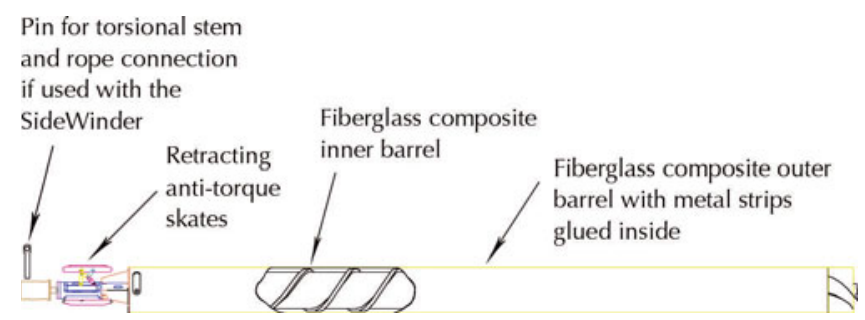

Fig. 2. Basic features of the PrairieDog drill design, showing a double-barreled torsion stem 4 in core drill with fiberglass inner and outer barrels. 
ground on the outside for a smooth finish and proper diameter. The inside surface is very smooth with a glass-like finish, having been formed over a polished mandrel, which is very good for chip transport. The fiberglass/epoxy barrel tube is both straighter and lighter than a comparable steel barrel. Three stainless-steel strips are glued longitudinally on the inside of the outer barrel with epoxy. These strips have remained tight after over $1000 \mathrm{~m}$ of drilling. Although five strips would provide a more stable bearing surface for the inner barrel, three have worked very well thus far. The outer barrel does not have cut-outs for enhanced chip pick-up but performs well without them.

The PrairieDog is interchangeable with the Polar Ice Coring Office (PICO) 4 in hand-auger (Koci and Kuivinen, 1984) core barrel since it uses the same coring head on the same size fiberglass/epoxy composite tubing for its inner barrel. The width of the augering flights of the original PICO 4 in hand-auger core barrel was reduced in the PrairieDog design to accommodate the stripped outer barrel while maintaining the same major diameter as the coring head. This greatly reduced the entire design scope since the same coring head is used. This also enables the two drills to be interchangeable, permitting one type to act as a back-up for the other in field operations.

The performance of the PrairieDog is limited in very soft snow and firn without the addition of 'snow blades', which have been designed but not yet tested. The addition of the snow blades will require future modification to the anti-torque section. At present, in order to overcome this limitation, the borehole is initiated with the 4 in PICO handauger core barrel and continues to the depth where the firn is dense enough for the PrairieDog anti-torque blades to grip the borehole sidewall.

\section{FURTHER DEVELOPMENT}

For applications where a smaller-diameter ice-core sample is desirable, a 3 in PrairieDog that could be used interchangeably with the 3 in PICO hand-coring auger would be beneficial, particularly if a significant number of cores are required to a depth of $10 \mathrm{~m}$ or greater.

\section{DISCUSSION AND CONCLUSION}

The PrairieDog significantly improves the efficiency of 'hand' augering to the practical limits of such a drilling system. It does not significantly increase the weight of the drill string, and saves trips into and out of the borehole if the depth of drilling is more than just a few meters. The ice cores produced are longer and have fewer breaks than those recovered with a single-barrel coring system, while the chips are more densely packed and are collected much more efficiently. The system has been used widely with good success, drilling for well over $1000 \mathrm{~m}$ to depths of up to $30 \mathrm{~m}$.

\section{ACKNOWLEDGEMENTS}

The PrairieDog was made using funds provided by NASA through the Program for Arctic Regional Climate Assessment (PARCA) and by the US National Science Foundation (NSF) Office of Polar Programs.

\section{REFERENCE}

Koci, B.R. and K.C. Kuivinen. 1984. The PICO lightweight coring auger. J. Glaciol., 30(105), 244-245. 